\title{
Do expected downturns kill political budget cycles?
}

\section{Frank Bohn ${ }^{1,2}$. Jan-Egbert Sturm ${ }^{3,4}$}

Published online: 12 August 2020

(C) The Author(s) 2020

\begin{abstract}
The political budget cycle (PBC) literature argues that governments expand deficits in election years. However, what happens when an economic downturn is expected? Will the government allow the deficit to expand even further, or will it resort to spending cuts and tax increases? When voters expect less than full automatic stabilization, our model shows that opportunistic government behavior leads to smaller deficits, thereby responding procyclically to expected downturns. Panel data evidence for 74 democracies covering the period 2000-2016 robustly supports the theoretical procyclicality prediction. Moreover, expected downturns remain significant when other context-conditional PBC effects are included in the empirical analysis.
\end{abstract}

Keywords Political budget cycles · Elections - Growth expectations · Economic downturns $\cdot$ Precautionary voters $\cdot$ Automatic stabilization $\cdot$ Fiscal deficits

JEL Classification D72 $\cdot$ E32 $\cdot$ E62

Electronic supplementary material The online version of this article (https://doi.org/10.1007/s11558-020-09379-w) contains supplementary material, which is available to authorized users.

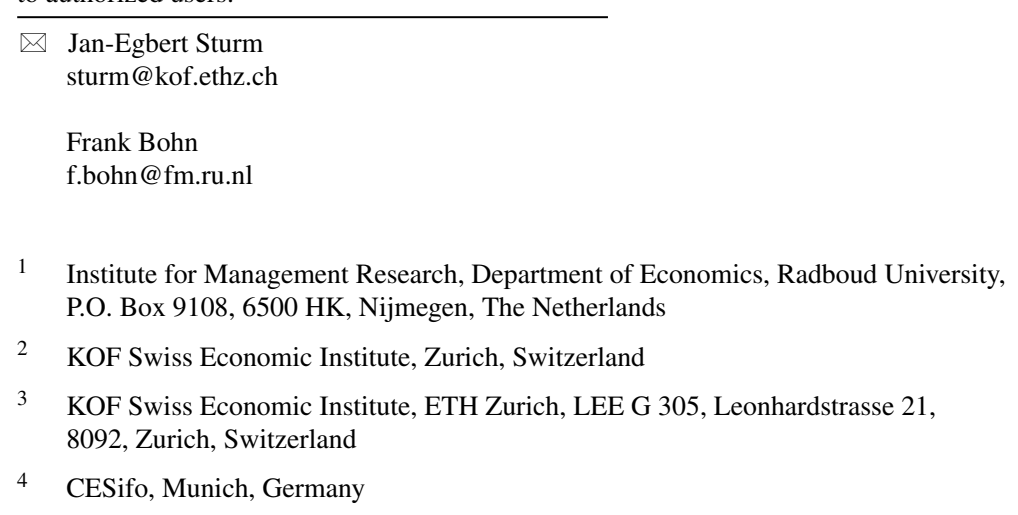




\section{Introduction}

In recent years, two main stylized facts have emerged from the empirical literature on political budget cycles (PBCs): (i) they are detected in a variety of fiscal policy variables; ${ }^{1}$ and (ii) they are context-conditional (i.e. PBCs do not always occur under all circumstances). ${ }^{2}$ What is missing, in our view, is research on a form of context-conditionality that has nothing to do with a country's type or institutions. How do opportunistic governments respond to the regular business cycle, more precisely, to expected changes in economic growth at the time of decision-making? ${ }^{3}$ We think this topic is important for two reasons. First, it is useful to understand under which circumstances opportunistic behavior creates distortions to fiscal policy and when not. That has probably also been the motivation for previous studies on context-conditionality. Second, we want to understand the underlying mechanism and develop a theoretical model for that. Even though expansionary fiscal policy is modeled to have a (more) beneficial multiplier effect in an economic downturn (which makes an increase in fiscal manipulation more advantageous), expected downturns may actually reduce the PBC effect. Our aim is to first theoretically show conditions under which such a reduction of political manipulation is feasible. We then proceed empirically and show that the PBC effect is virtually eliminated when downturns are expected.

However, this does not happen because political opportunism has suddenly vanished. In an election year, as in an off-election year, any government that expects a worsening of economic conditions must choose between conducting additional

\footnotetext{
${ }^{1}$ They occur, for instance, in debt, public expenditures, especially transfers, and expenditure shares. Evidence for cycles in debt is provided by Alesina et al. (1992) and Alesina et al. (1993) and Alesina and Roubini (1990), and confirmed by Drazen (2001). The notion of cycles in public expenditures and particularly transfers is supported by, for instance, Schuknecht (1996; 2000); Block (2002); Drazen (2001); Vergne (2009) and Schneider (2010). Cycles in expenditure shares are suggested by Veiga and Veiga (2007), Drazen and Eslava (2010), Benito et al. (2013), Aidt and Mooney (2014), Castro and Martins (2016), Klomp and De Haan (2016), and Arifin and Purnomowati (2017).

${ }^{2}$ The term was coined by Franzese (2002) and picked up by e.g. Alt and Rose (2007) and Dubois (2016). PBCs can be found, for instance, in countries with limited checks and balances or access to free media (Alt and Lassen 2006a, b; Akhmedov and Zhuravskaya 2004; Klomp and De Haan 2016; and Veiga et al. 2017), in developing countries (Schuknecht 1996 and 2000; Block 2002; Shi and Svensson 2006; and Vergne 2009), or in new democracies (Brender and Drazen 2005), and are affected by the political system (Chang 2008 and Streb et al. 2009) and/or the electoral system (Aidt and Mooney 2014). Bojar (2017) discusses how individual characteristics favor the occurrence of PBCs. A literature survey is provided by De Haan and Klomp (2013).

${ }^{3}$ There are many articles that focus on the relationship between economic fluctuations and electoral support for re-election chances. See, for instance, Lewis-Beck and Stegmaier (2000), Brender and Drazen (2008), and Chang and Lee (2010) and Goulas et al. (2015). However, we are only aware of two papers that look into the effects of recession expectations on fiscal outcomes: Bohn and Veiga (2019a, b). These papers concentrate on decision-making at the municipality level and produce results that are quite opposite, both theoretically and empirically, from ours.
} 
expansionary policies (to augment the countercyclical effect of automatic stabilisers ${ }^{4}$ that are already in the system), or instituting precautionary spending cuts or tax increases (to cope with the deteriorating fiscal budget caused by automatic stabilisers). However, in an election year, opportunistic behavior might distort such considerations. The political budget cycle literature suggests an already elevated level of the deficit in normal election years. So, why not, in order to make up for the expected loss in tax revenues (and/or increase in benefit payments), expand the deficit even further when an economic downturn is expected to hit in an election year? Would this not preserve the incumbent government's fiscal latitude and with it its chance of winning the elections? The answer is that a government does not necessarily have to increase its fiscal latitude to increase its re-election chances; it merely needs to be more expansionary than what voters expect. If voters believe the government will not allow full automatic stabilization (through decreased tax revenues and/or increased benefit payments) in case of an expected economic downturn, but expect some spending cuts (or tax increases), it is sufficient for the government to make more moderate spending cuts (or tax hikes) than expected by voters. ${ }^{5}$

Based on panel data for 74 democracies covering the years 2000 until 2016, we study the impact of country-specific forecasts (our proxy for expectations) on government primary budget balances. To get a first idea, the effect of an expected downturn on the political budget cycle is visualized in a naive way in Fig. 1. We split our sample into data points with normal and high expected growth on the one hand and expected downturns on the other hand. ${ }^{6}$ For each sub-sample, we subtract the mean of the primary balances in election years from the mean of the primary balances in nonelection years. We interpret this as a measure of the PBC effect for each sub-sample. As we can see in Fig. 1, the PBC effect is much larger when no downturn is expected. Admittedly, this is a very crude representation (deprived of econometric rigor), but it captures our idea that expected downturns do not make the government increase its manipulation effort. Instead, the PBC effect is actually reduced considerably.

In our empirical analysis in Sections 5 to 7, we show that this decline becomes even more pronounced than depicted in Fig. 1 when we control for other factors.

\footnotetext{
${ }^{4}$ Note the use of terminology here. Automatic stabilisers are said to typically have a countercyclical effect. Keynesian discretionary policy is also countercyclical. Precautionary discretionary policy (in a recession or expected recession) is procyclical. In as far as automatic stabilisers are associated with countercyclicality we follow the usage as, for instance, in Seidman (2015) while acknowledging that other definitions are also possible.

${ }^{5}$ Theoretically, another, more indirect, explanation would also be feasible. It would be related to Peltzman's (1992) idea of fiscal conservatism. Alesina et al. (1998), Brender (2003), and Brender and Drazen (2008) show that voters may actually punish incumbents for increasing fiscal deficits. (Some) voters dislike deficits and, therefore, dislike even more a spurt of the deficit associated with a downturn. There might be a trade-off between a PBC effect and a fiscal conservatism effect. Under normal economic conditions, the PBC effect might dominate, while the deficit dislike effect would dominate under strained economic conditions that require higher deficits. In contrast, the theoretical analysis here argues that the PBC effect is affected (actually annulled) by the expected downturn itself, not the level of the deficit.

${ }^{6}$ The definition of an expected downturn is when a country expects a growth rate that is more than one standard deviation below the average realized growth observed during the previous five years. See also Footnote 20.
} 


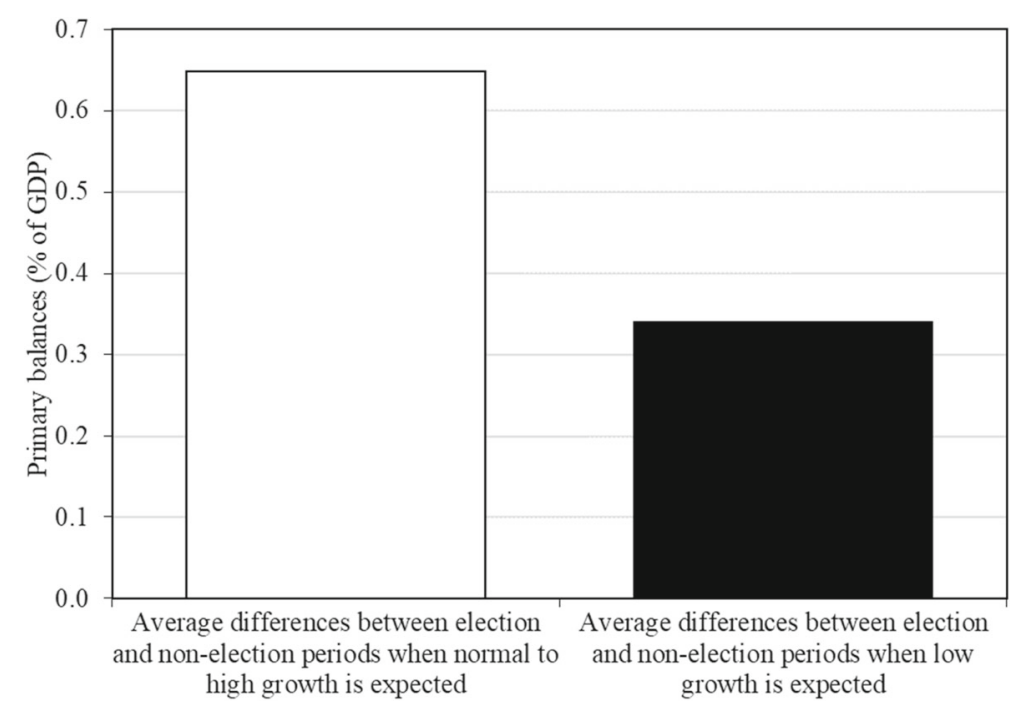

Fig. 1 Primary Balance, by growth expectations and election years

There we distinguish between effects of realized and expected economic conditions and use an empirical strategy analogous to difference-in-differences estimation. We find that realized downturns have a strong and highly significant countercyclical effect on the deficit due to automatic and/or discretionary stabilization policy (an effect that does not differ between election and off-election years).

For expected downturns (that do not necessarily materialize) the situation clearly differs between election and off-election years. In the latter case, deficits go up in almost all specifications, though mostly not significantly; governments may have a tendency to act countercyclically when an economic downturn is expected. Election years are different: when controlling for realized growth, election years have a procyclical expected downturn effect that is significant in all specifications as suggested by our theoretical model. The effect is so strong that, on average, it eliminates the traditional PBC effect. Moreover, taking account of other conditionalities for political budget cycles does not destroy this election year procyclicality effect of expected downturns.

The rest of the paper is structured as follows: Section 2 lays out and solves a political budget cycle model that incorporates automatic stabilization as well as downturn expectations while carefully distinguishing realized growth from expected growth and realized deficit from expected deficit. In Section 3, we allow voters to underestimate automatic stabilization and derive a proposition that explains the elimination of the traditonal PBC effect. Section 4 describes the data and the empirical model, while Section 5 presents and discusses the core empirical findings. Sections 6 and 7 offer an array of robustness checks. Section 8 concludes. 


\section{The general model}

The general model captures opportunistic policy making by an incumbent who faces electoral competition from a single challenger. Election and off-election periods alternate. Agents have growth expectations which may or may not be rational and may or may not differ between voters and politicians. Without limiting the general validity of the analysis, we focus on economic downturns and expectations thereof. In the theoretical model, a downturn means growth below trend.

\section{Agents}

Voters $i$ and politicians $j$ maximize utility from the perspective of current period $t$ ( $U_{t}^{i}$ and $V_{t}^{j}$, respectively), which is the expected net present value of an economic and a political component in each period; $\beta^{i}$ and $\beta^{j}$ are the respective discount factors; and $E$ is the expectation operator. Voters' period utility comprizes of additivelyseparable utility from consumption, $c_{s}$, and from their personal sympathy for the politician in power, $\theta^{i} z_{s}$ (with weight $\alpha$ ).

$$
U_{t}^{i}=\sum_{s=t}^{\infty}\left(\beta^{i}\right)^{s-t} E_{s}^{i}\left[c_{s}+\alpha \theta^{i} z_{s}\right], \quad i=1, \ldots, n .
$$

Utility derived from sympathy is constrained to $\theta^{i} z_{s} \in\left[-\frac{1}{2}, \frac{1}{2}\right]$ since $z_{t}$ is either $-\frac{1}{2}$ (when politician $a$ is elected) or $+\frac{1}{2}$ (when politician $b$ is elected) and the personal sympathy (or ideological orientation) parameter $\theta^{i}$ is uniformly distributed over the interval $[-1,1]$. Without limiting the general validity of the analysis, we assume that politician $a$ is in power. Hence, voters favoring politician $a$ gain positive utility, though less if their preferences are closer to the center of the spectrum. Moderate voters with a slight preference for politician $b$ could be convinced by incumbent $a$ to vote for her, if they expect her to provide enough additional economic utility to compensate for voting for the "wrong" politician. (See also Eq. 6.)

The politicians' period utility depends on the same utility from consumption, but the political component captures the perks from being in power, i.e. the so-called ego rent $X$ which is assumed to be constant over time:

$$
V^{j}=\sum_{s=t}^{\infty}\left(\beta^{j}\right)^{s-t} E_{s}^{j}\left[c_{s}+\mathbf{I}_{s} X\right] ; \quad j=a, b ; \quad \mathbf{I}_{s}= \begin{cases}1 & \text { if in power in period } s ; \\ 0 & \text { otherwise }\end{cases}
$$

Period consumption $c_{t}$ is modeled to depend on period income $Y$ (which depends on the growth factor of the economy $\gamma_{t}$ ) minus tax revenues $T$ (which also depend on $\gamma_{t}$ ). For simplicity, we call $\gamma_{t}=\bar{\gamma}$ trend or average growth, $\gamma_{t}<\bar{\gamma}$ a downturn, and $\gamma_{t}>\bar{\gamma}$ a boom. In addition, discretionary public spending $G_{t}^{a}$, for instance infrastructure investment, may have a net impact on output and hence on consumption depending on fiscal multiplier $m$ (see, for instance, Ilzetzki et al. 2013) which, again, depends on $\gamma_{t}$ :

$$
c_{t}=Y\left(\gamma_{t}\right)-T\left(\gamma_{t}\right)+m\left(\gamma_{t}\right) G_{t}^{a} .
$$

This simple structure allows us to distinguish between automatic stabilization and discretionary policies. $T$ captures automatic stabilization (with discretionary changes 
to taxation being ruled out) and $G$ represents discretionary government spending (whereas automatic stabilization effects on government spending are ignored). Assumptions on the three functions with argument $\gamma$ can be very general. Obviously, $Y^{\prime}(\gamma)>0 . T^{\prime}(\gamma)>0$ ensures that there is automatic stabilization. What the government can influence is $G_{t}^{a}$. The net effect discretionary fiscal policy has on the economy could be left open $\left(m^{\prime}(\gamma) \lessgtr 0\right)$. However, Auerbach and Gorodnichenko (2012) find that during recessions the effect rises above 1 after four quarters, but drops below zero during expansions. For our purposes it suffices to assume that the multiplier is larger in downturns than in booms, $m^{\prime}(\gamma)<0{ }^{7}$

\section{Discretionary fiscal policy and the timing of events}

Through discretionary fiscal spending $G_{t}^{a}$ incumbent $a$ has the possibility to influence consumption and thereby reelection chances. In the model, the incumbent uses her (only) policy instrument, planned deficit $\breve{D}_{t}^{a}$, to finance $G_{t}^{a}$ while taking account of expected tax revenues $T\left(\breve{\gamma}_{t}\right){ }^{8}$ The government budget constraint at the stage of planning is:

$$
G_{t}^{a}=\breve{D}_{t}^{a}+T\left(\breve{\gamma}_{t}\right)-R\left(D_{t-1}\right)+\eta_{t}^{a} .
$$

$T\left(\breve{\gamma}_{t}\right)$ (with $\breve{\gamma}_{t}$ being the government's growth perception) captures expected automatic stabilization effects. The level of fiscal spending $G_{t}^{a}$ is also influenced by deficit repayment costs $R\left(D_{t-1}\right)$ (which is a continuous function of public borrowing with $R(0)=0, R^{\prime}(0)=1$, as well as $R^{\prime \prime}(D)>0$ for all $D>0$ ). Furthermore, we follow Rogoff (1990) by assuming that fiscal spending $G_{t}^{a}$ is also affected by government competence $\eta_{t}^{a}$ which comprizes a stochastic MA(1) process made up of an i.i.d. skills shock for the previous period, $v_{t-1}^{a}$, and another one for the current period, $v_{t}^{a}$ :

$$
\eta_{t}^{a}=v_{t}^{a}+v_{t-1}^{a}
$$

Shocks $v_{t}^{a}$ are random variables with mean 0 and distribution function $F\left[v_{t}^{a}\right]=F[\bullet]$. For simplicity, density function $f\left[v_{t}^{a}\right]=f[\bullet]=F^{\prime}[\bullet]$ is assumed to be bell-shaped. Current period skills shock $v_{t}^{a}$ cannot be observed by the incumbent (or voters) at the government policy planning stage. Hence, the government cannot observe the level of government spending that will be provided in the end.

The timing of events is summarized in Table 1. In election period $t$, (i) voters and incumbent $a$ recall the deficit and the skills of the incumbent in the previous period and (ii) form expectations - the incumbent on growth and voters on growth and the deficit. The $n$, (iii) the incumbent maximizes her utility by choosing the planned deficit and, thereby, providing discretionary fiscal policy $G_{t}^{a}$. Finally, (iv) voters form expectations of the incumbent's current period skills based on their expectations of growth and the deficit (from (ii)) and their observation of the level of discretionary

\footnotetext{
${ }^{7}$ The larger multiplier effect in recessions implies that it should be even more attractive for the government to boost spending during expected downturns. This biases our model against our results. In other words, it is harder to obtain the result that government manipulation leads to spending cuts and thereby to a reduction or elimination of the political budget cycle when a downturn is expected.

${ }^{8}$ Note that $T\left(\breve{\gamma}_{t}\right)$ are the tax revenues to be obtained for expected growth factor $\breve{\gamma}_{t}$. Note also that $G_{t}^{a}$ is actual spending (not just a plan) because actual resources must correspond to planned resources, $D_{t}+$ $T\left(\gamma_{t}\right)=\breve{D_{t}^{a}}+T\left(\breve{\gamma}_{t}\right)$, according to Eq. 16 in Appendix A.
} 
Table 1 The Timing of Events

\begin{tabular}{|c|c|}
\hline Time & Who does what? \\
\hline Period $t$ & $\begin{array}{l}\text { i) Voters } i \text { and incumbent } a \text { observe: } \\
\text { - last period deficit, } D_{t-1} \text {; } \\
\text { - the incumbent's last period skills, } v_{t-1}^{a} \text {. } \\
\text { ii) Expectations are formed by: } \\
\text { - voters } i \text { on growth factor } \widehat{\gamma}_{t} \text {; } \\
\text { - voters } i \text { on the deficit, } \widehat{D}_{t} \text {; } \\
\text { - incumbent } a \text { on growth factor, } \breve{\gamma}_{t} \text {. } \\
\text { iii) Incumbent } a \text { : } \\
\text { - chooses planned deficit, } \breve{D}_{t}^{a} \text {; } \\
\text { - thereby setting discretionary fiscal policy, } G_{t}^{a} \text {. } \\
\text { iv) Voters } i \text { : } \\
\text { - observe discretionary policy, } G_{t}^{a} \text {; } \\
\text { - form expectations of the incumbent's current period skills, } \widehat{v}_{t}^{a} \\
\text { (based on expected growth factor, } \widehat{\gamma}_{t} \text {, and expected deficit, } \widehat{D}_{t} \text {; } \\
\text { - and vote. }\end{array}$ \\
\hline Period $t+1$ & $\begin{array}{l}\text { The winner of the period } t \text { elections takes office and receives an ego rent. } \\
\text { Eventually, the winner repays the deficit of the previous period. }\end{array}$ \\
\hline
\end{tabular}

policy (from (iii)). If they are above average, they expect the incumbent to provide higher economic utility in the next period than the challenger (whose skills are expected to be average). Some moderate voters with a slight preference for politician $b$ can thus be swayed to vote for incumbent $a$. What happens in off-election period $(t+1)$ is stated in Table 1. Explanations on this and why the model can be split into cycles consisting of election periods $\mathrm{t}$ and off-election periods $(t+1)$ are given in Appendix A.

\section{Model solution}

In period $t$, prospective voters compare their period $(t+1)$ utility from incumbent $a$ being in power to their utility from challenger $b$ being in office. We show in Appendix B that any voter $i$ will vote for incumbent $a$, if her perception of government skills, $E_{t}^{i}\left[v_{t}^{a}\right]$, makes more than up for the "wrong" ideological orientation of the incumbent $\left(\theta^{i}>0\right)$ :

$$
E_{t}^{i}\left[v_{t}^{a}\right] \geq \alpha \theta^{i}
$$

Voters use government budget constraint 4 to extract competence (for details see Appendix C). Since they cannot directly observe the actual deficit and the growth factor, their expectation of government competence and hence the winning chances of the incumbent depend on the voters' misperception of the available revenues from taxation and deficit:

$$
\operatorname{Prob}^{\text {win }}=1-F\left[\left(T\left(\widehat{\gamma}_{t}\right)+\widehat{D}_{t}\right)-\left(T\left(\gamma_{t}\right)+D_{t}\right)\right] .
$$


Let us first consider a situation without actual and expected downturns $\gamma_{t}=\widehat{\gamma}_{t}=\bar{\gamma}$, which implies that the $T$ terms in the bracket cancel each other out (which would, of course, also be the case when growth expectations simply corresponded to realized growth). Given the zero mean property of the skills shock (Eq. 5, see also Fig. 4 in Appendix C) the winning probability can only be increased, if the realized deficit $D_{t}$ is expanded beyond what voters expect $\left(\widehat{D}_{t}\right)$. This is the moral hazard motivation for politico-economic manipulations by the incumbent suggested by Shi and Svensson (2006). In case of an actual downturn $\left(\gamma_{t}<\bar{\gamma}\right)$ or an expected one $\left(\widehat{\gamma}_{t}<\bar{\gamma}\right)$, it depends on the voters' overestimation of resources $\left(T\left(\widehat{\gamma}_{t}\right)+\widehat{D}_{t}\right)$ relative to the actually available resources $\left(T\left(\gamma_{t}\right)+D_{t}\right)$. If voters expect a higher level of discretionary fiscal policy than what the government provides (i.e. overestimate resources), they think the government is incompetent and will vote it out of office. Equation 7 also shows that government manipulations beyond what voters believe can increase the winning probability.

The first-order condition (FOC) of incumbent $a$ 's decision problem can be simplified as follows (for the maximisation problem itself and further details see Appendix D):

$$
m(\bar{\gamma}) R^{\prime}\left(\breve{D}_{t}^{a}\right)-m\left(\breve{\gamma}_{t}\right)=F^{\prime}\left[\left(T\left(\widehat{\gamma}_{t}\right)+\widehat{D}_{t}\right)-\left(T\left(\breve{\gamma}_{t}\right)+\breve{D}_{t}^{a}\right)\right] X .
$$

With the second-order condition for a maximum verified, the FOC fully characterizes the government's optimally planned deficit choice $\breve{D}_{t}^{a}=\left(\breve{D}_{t}^{a}\right)^{*}$. It says that the net marginal repayment cost from expanding the planned deficit (the foregone multiplier effect in $(t+1), m(\bar{\gamma}) R^{\prime}\left(\breve{D}_{t}^{a}\right)$, minus the expected multiplier effect in $\left.t, m\left(\breve{\gamma}_{t}\right)\right)$ must equal the electoral manipulation effect (the marginal increase in the chance of winning, $F^{\prime}[\bullet]$, times the ego rent $X$ ). Raising the planned deficit is advantageous because the incumbent can appear more competent and thus increase its chance of winning and staying in office. This is the standard (moral hazard) electoral manipulation motive suggested by Shi and Svensson (2006) (even if this does not increase re-election chances under rational expectations - as discussed in Appendix E). Note, however, that our model delivers an additional (Keynesian) motive. With the multiplier effect being larger in a downturn $(m(\gamma<\bar{\gamma})>m(\bar{\gamma}))$, it is optimal for the incumbent to shift costly resources to a downturn period. ${ }^{9}$

\section{Underestimated automatic stabilization}

In this section, we present and discuss the results when deviating from the rational expectations assumption with respect to the voters' response to a downturn. In Appendix E we consider rational expectations and show what happens when there is no downturn and how expected downturns affect the rational expectations outcome.

\footnotetext{
${ }^{9}$ This also applies in the absence of an electoral manipulation motive (as it would be in a downturn in non-election times). It does, however, not apply to off-election period $(t+1)$ in our model, because the incumbent does not know about the growth prospects for the off-election period (and hence assumes $\gamma_{t+1}=\bar{\gamma}$ ) when she takes a decision about electoral manipulation in period $t$.
} 


\section{Deviations from Rational Expectations (RE)}

The raw data averages presented in the Introduction suggest that the deficit expansion in an election year is much lower when a downturn is expected. As shown in Appendix E, the RE assumption allows us to produce a PBC in normal (nondownturn) times, but not that it is reduced (or even eliminated) when a downturn is expected. We continue to postulate that voters foresee the recurrent political manipulations in election times - as already suggested by Shi and Svensson (2006). However, we allow them to underestimate the consequences of the expected automatic stabilization. ${ }^{10}$ This can be justified in at least two ways. First, it may be due to rational inattention (Sims 2003). Voters may rationally shy away from obtaining costly information that would allow them to foresee the upcoming downturn to the same extent as the government, or to fully understand the effects of automatic stabilization. Second, voters may think the government should or will not allow (full) automatic stabilization to take effect. ${ }^{11}$ If either holds, it would amount to voters "underestimating" the consequences of automatic stabilization.

Irrespective of its cause, we would like to explore the implications of underestimated automatic stabilization. Let us distinguish between normal election years and downturn election years by splitting the deficit variables: the realized deficit becomes $D_{t}=D_{t}{ }^{\text {nor }}+D_{t}^{\text {down }}$; the planned deficit becomes ${\breve{D_{t}^{a}}}^{a}=\left(\breve{D}_{t}^{a}\right)^{\text {nor }}+\left(\breve{D}_{t}^{a}\right)^{\text {down }}$; and the deficit expected by voters becomes $\widehat{D}_{t}=\left(\widehat{D}_{t}\right)^{\text {nor }}+\left(\widehat{D}_{t}\right)^{\text {down }}$. (The "down" component of realized, planned and expected deficit always refers to the additional deficit compared to the "normal" component, i.e. it comprises the deficit produced by automatic stabilization and the correction by discretionary behavior, realized, planned or expected.) The government budget constraint 4 becomes (when also replacing deficit repayment $R\left(D_{t}\right)$ by $(1+r) D_{t}$ with $r$ being an exogenous interest rate):

$$
G_{t}^{a}=T(\breve{\gamma})+\left(\breve{D}_{t}^{a}\right)^{\text {nor }}+\left(\breve{D}_{t}^{a}\right)^{\text {down }}-(1+r) D_{t-1}+\eta_{t}^{a} .
$$

The realized deficit (ex post), Eq. 16 of Appendix A, becomes

$$
D_{t}^{\text {nor }}+D_{t}^{\text {down }} \equiv\left(\breve{D}_{t}^{a}\right)^{\text {nor }}+\left(\breve{D}_{t}^{a}\right)^{\text {down }}+T\left(\breve{\gamma}_{t}\right)-T\left(\gamma_{t}\right)
$$

Since the incumbent makes no mistake in estimating government revenue in normal times by construction (see also Footnote 38 of Appendix E), $D_{t}^{n o r}=\left(\breve{D}_{t}^{a}\right)^{\text {nor }}$ and

$$
D_{t}^{\text {down }} \equiv\left({\breve{D_{t}^{a}}}^{\text {down }}+T\left(\breve{\gamma}_{t}\right)-T\left(\gamma_{t}\right)\right. \text {. }
$$

\footnotetext{
${ }^{10}$ This is a different approach to the ones taken in Bohn (2018) and Bohn (2019). In the former, voters are unsophisticated and cannot rationally expect the government manipulation. In the latter, the government can use its incumbency advantage to use propaganda in order to influence voters' beliefs.

${ }^{11}$ According to the Rasmussen Reports (2010) $75 \%$ of American voters are sceptical towards automatic stabilization; “... only $11 \%$ of American adults agree and think the nation needs to increase its deficit spending [in tough economic times]. ... 70\% disagree and say it would be better to cut the deficit [in such cases]." It is not inconceivable that there is scepticism in other countries, too, which might translate into voter expectations of precautionary government behavior.
} 
As a result, the FOC is now

$$
\begin{aligned}
& m(\bar{\gamma})(1+r)=m\left(\breve{\gamma}_{t}\right)+ \\
& F^{\prime}\left[\left(T\left(\widehat{\gamma}_{t}\right)+\left(\widehat{D}_{t}\right)^{\text {nor }}+\left(\widehat{D}_{t}\right)^{d o w n}\right)-\left(T\left(\gamma_{t}\right)+\left(D_{t}\right)^{\text {nor }}+\left(D_{t}\right)^{\text {down }}\right)\right] X .
\end{aligned}
$$

At this point, we have to specify the different assumptions for $\left(\widehat{D}_{t}\right)^{\text {nor }}$ and $\left(\widehat{D}_{t}\right)^{\text {down }}$. Voters' rational expectations for the deficit in normal times means $\left(\widehat{D}_{t}\right)^{\text {nor }}=\left(\breve{D}_{t}^{a}\right)^{\text {nor }}=\left(D_{t}\right)^{\text {nor }}$. However, voters may underestimate the tax revenue effect of automatic stabilization of an expected downturn on the deficit:

$$
\left(\widehat{D}_{t}\right)^{\text {down }}=e\left(T(\bar{\gamma})-T\left(\widehat{\gamma}_{t}\right)\right), \quad 0 \leq e \leq 1 .
$$

$T(\bar{\gamma})-T\left(\widehat{\gamma}_{t}\right)$ is underestimated by factor $e<1(e=1$ would be the correct prediction).

To determine how the incumbent responds to the additional deficit expectations by voters in a downturn, we have to start from the FOC, Equation 12, which becomes:

$$
m(\bar{\gamma})(1+r)=m\left(\breve{\gamma}_{t}\right)+F^{\prime}\left[\left(T\left(\widehat{\gamma}_{t}\right)+e\left(T(\bar{\gamma})-T\left(\widehat{\gamma}_{t}\right)\right)-\left(T\left(\gamma_{t}\right)+\left(D_{t}\right)^{\text {down }}\right)\right] X\right.
$$

The FOC has to hold, even though the components of $\breve{D}_{t}^{a}$, the government's instrument, are now replaced by the components of actual deficit $D_{t}$. The government's downturn expectations play no role, except for the magnitude of the multiplier effect. What matters are the voters' downturn expectations, which will be exploited in Proposition 1.

\section{Proposition 1 - Effect of Worsening Growth Expectations.}

Consider the incumbent government's optimal response, at the equilibrium, to marginally worsening growth expectations in an election year:

(i) If the growth expectations of voters worsen (but not those of the incumbent), the actual deficit goes down procyclically, if automatic stabilization is at least marginally underestimated by factor $e<1$ :

$$
\frac{d D_{t}}{d \widehat{\gamma}}>0 \quad \text { if and only if } e<1
$$

(ii) If the growth expectations of voters and incumbent alike worsen, the actual deficit goes down procyclically, if automatic stabilization is clearly underestimated:

$$
\frac{d D_{t}}{d \widehat{\gamma}}>0 \text { if and only if } e<1-w \text {, where } w=-\frac{m^{\prime}\left(\tilde{\gamma}_{t}\right)}{F^{\prime \prime} X T^{\prime}\left(\tilde{\gamma}_{t}\right)}>0 \text {. }
$$

Proof: Appendix F.

What matters is that the incumbent understands that there are (worsening) growth expectations by voters. If there is some underestimation of the degree of automatic 
stabilization by voters, ${ }^{12}$ they will underestimate the government's willingness to run higher deficits. This allows the incumbent to cut spending (i.e. reduce automatic stabilisation in a discretionary way) in order to limit deficit repayment costs, while still increasing the deficit by more than what voters expect. Voters will be surprised by the, from their perspective, high level of government spending, attribute it to competence and vote for the incumbent.

The threshold for the underestimation factor $e$ differs depending on whether the government shares the voters' beliefs. If the incumbent also believes in the (worsening) downturn, the multiplier is expected to increase as well. This makes discretionary spending more attractive for the incumbent (see Footnote 7). Hence, the incumbent tends to produce a higher deficit. For the procyclicality result to hold, nonetheless, the voters' underestimation of the degree of automatic stabilization must be larger, i.e. $e<1-w$. In either case, the procyclicality result can be obtained with a sufficient degree of underestimation of the degree of automatic stabilization.

\section{Empirical set-up and the data}

The main prediction of the theoretical model is that the political budget cycle effect could differ depending on expected economic conditions. In case the government expects an economic downturn while preparing for upcoming elections, it will budget a higher public deficit, but with a smaller increase than implied by (i) automatic stabilization as expected in non-election years and (ii) the political budget cycle effect (as we know it from election years in economically normal times) taken together. Translated into an empirical framework this implies that conditional on actual growth, expecting a downturn when elections are upcoming leads to an actually improved fiscal situation. This is what we are testing in this part of the paper. The equation we estimate is the following:

$$
\begin{aligned}
\text { FiscalBalance }_{i t}= & \beta_{1} \text { RealizedGrowth }_{i t}+\beta_{2} \text { Election }_{i t}+\beta_{3} \text { ExpectedEconomy }_{i t} \\
& +\beta_{4}\left(\text { Election }^{*} \text { Expected Economy }_{i t}\right. \\
& +\gamma \text { Controls }_{i t}+\alpha_{i}+\tau_{t}+\varepsilon_{i t} .
\end{aligned}
$$

By including both country- $\left(\alpha_{i}\right)$ and year-fixed $\left(\tau_{t}\right)$ effects, this resembles a difference-in-differences estimation strategy. In order to have enough variation and degrees of freedom, we focus on a large set of democratic countries and as many years as possible while still being able to distinguish between realized and expected

\footnotetext{
${ }^{12}$ Here is an alternative interpretation suggested by one of the reviewers. In principle, Eq. 13 could be rewritten in terms of tax revenue elasticity times the expected change in output. Voters might underestimate the short-term elasticity of tax revenue with respect to the cycle which is typically above 1 . They might, for instance, confuse it with the long-term unit elasticity. Such an underestimation would also produce the procyclicality result obtained in Proposition 1. This interpretation would actually give us some empirical substantiation of our theoretical condition.
} 
economic conditions. In defining democracies, we only use countries that are classified as 'free' by Freedom House. This definition is more restrictive than, for instance, the classification by Cheibub et al. (2010), which we use as a robustness check. ${ }^{13}$ Forecasts are taken from the IMF World Economic Outlook (IMF WEO) publications. The first issue available to us that contains the data necessary for our analysis was published in April 1999. This allows us to use a slightly unbalanced panel of 74 countries covering the period 2000-2016.

Our dependent variable, Fiscal Balance, is the general government primary fiscal balance taken from the IMF World Economic Outlook published in April 2019. ${ }^{14}$ To allow comparisons across countries while at the same time assuring that economic developments during the year are not directly included in our dependent variable, we divide the primary balance by lagged GDP. ${ }^{15}$ As interest payments are hardly under government control over a time horizon that is relevant to us, we focus on the primary balance. $^{16}$

Upcoming elections (Election) is one of our key explanatory variables. This information is taken from the Database of Political Institutions (DPI) as described in Cruz et al. (2018) which is an updated version of Beck et al. (2001). ${ }^{17}$ Following, for instance, Shi and Svensson (2006), Vergne (2009), Gupta et al. (2015), and Hayo and Neumeier (2016), we include legislative elections for countries with parliamentary (or assembly-elected) political systems, while for countries with presidential systems we consider executive elections. ${ }^{18}$

Turning to the economic conditions we measure realized real GDP growth (RealizedGrowth ${ }_{i t}$ ) using the latest information as contained in the April 2019 IMF World Economic Outlook. ${ }^{19}$ Expected economic conditions (ExpectedEconomy $y_{i t}$ ) are measured in two different ways, both based on real GDP growth forecasts as published in the November issue of the IMF WEO the year before $(t-1)$. These or

\footnotetext{
${ }^{13}$ They code a regime as democratic in case i) the executive and legislative branches are elected and ii) multiple parties are allowed and exist. The qualitative results are not affected by this (see Table 3).

${ }^{14}$ Unfortunately, we do not have access to sufficient data that focus on the central government only. Hence, we assume that the central government does have some influence on lower layers of the government. To the extent that this does not hold, it should make it more difficult for us to find significant effects.

${ }^{15}$ The qualitative results do not depend on whether we divide the primary deficit by lagged GDP or contemporaneous GDP.

${ }^{16}$ As a robustness check, we also carry out the same analysis using the fiscal balance instead of the primary fiscal balance. As shown in Table G.2 of Appendix G, the conclusions do not change.

${ }^{17}$ In general, we use the variables EXELEG and LEGELEC that indicate whether there was an executive or legislative election in a particular year. In column (5) of Table 3 and column (2) of Table G.3 in Appendix G, we use the variable YRCURNT (years left in current term) to determine election years. When using YRCURNT, we incorporate the corrections proposed by Christopher Gandrud. See https://thepoliticalmethodologist.com/2015/03/03/corrections-and-refinements-to-the-databaseof-political-institutions-yrcurnt-election-timing-variable/. Our qualitative results do not dependent on these corrections.

${ }^{18}$ In parliamentary democracies, elections of the legislature coincide with those of the executive. In presidential democracies, the executive is elected separately, but the legislature is almost always elected in the same year.

${ }^{19}$ If we use instead the June publication of the IMF WEO in the following year $(t+1)$, i.e. the first release of the realised growth rate, the conclusions are not affected (see column (3) of Table G.3 in Appendix G).
} 
slightly earlier published forecasts form the basis for the budgeting process of the fiscal authorities. To stick as closely as possible to our theoretical model, we create an expected downturn dummy to capture expected below trend growth. The dummy indicates whether a country expects a growth rate that is more than one standard deviation below the average realized growth observed during the previous five years. ${ }^{20}$ As a second measure, we use the growth forecasts directly. ${ }^{21}$ Instead of assuming a step function, we then imply that the effect of an upcoming election depends linearly on growth expectations. To check whether this linearity assumption makes sense, we follow Hainmueller et al. (2019) and apply flexible binning and kernel estimations. The results suggest that the interaction is indeed linear. ${ }^{22}$ To facilitate the interpretation of the coefficient estimate of $\beta_{3}$ in Eq. 15, we de-mean expected growth rates at the country level. This means that a positive value represents an above average expected growth rate for the respective country. A negative value captures below average expected growth.

To correct for any non-time-varying country-specific and non-country-varying time-specific characteristics, we include country- and time-fixed effects in our specifications. By including further control variables, we both intend to reduce potential endogeneity problems and the size of the estimated standard errors. Based on previous literature (like Roubini and Sachs (1989), De Haan et al. (1999)), we select inflation, general government gross debt (as percentage of GDP), population growth (all three from the IMF WEO), and the age dependency ratio (from the World Bank, World Development Indicators (WB WDI)) as potential control variables. On top of that, we also include a measure for globalization: the KOF Globalisation Index (see Gygli et al. (2019) and Dreher (2006)). All of these are lagged by one period to reduce reverse causality problems. Revenues received out of selling natural resources like oil and gas potentially drive the fiscal budgets of some countries. To control for that, we include national resource rents (as percentage of lagged GDP) as published in the WB WDI in our regressions. Finally, countries that have an arrangement with the IMF might be in a different situation regarding their fiscal position. Aldenhoff (2007), Dreher et al. (2008), and Atoyan and Conway (2011), for instance, argue that IMF forecasts might be biased, if a country is under an IMF program. We, therefore, also include a dummy variable for being under an IMF program, which is taken

\footnotetext{
${ }^{20} \mathrm{We}$ thank an anonymous reviewer for this suggestion. If instead we use the lower quartile of the countryspecific distribution of growth forecasts, the qualitative results do not change (see column (4) of Table G.3 in Appendix G). Initially, we also intended to use an expected recession dummy to indicate expected negative growth. However, recessions are quite rare events; they occur in less than $4 \%$ of the country-year observations in our sample. Combining this with elections that occur roughly every fourth year would have meant that we base the coefficient estimates of the interaction effect $\left(\beta_{4}\right)$ on only a limited number of (extreme) cases.

${ }^{21}$ The correlation coefficient between elections and the expected downturns equals 0.01 and is not significantly different from zero. The correlation of the election variable with the expected growth rate is -0.03 (and again not significantly different from zero). It is, therefore, empirically safe to say that elections and our expected economy variables are orthogonal to one another.

${ }^{22}$ As stressed by Hainmueller et al. (2019), this should and does in our case especially hold around those growth expectations for which both election and non-election periods are observed, i.e. when there is sufficient common support.
} 
from the IMF MONA database. All of these variables are summarized in Table G.1 in Appendix G. ${ }^{23}$

\section{Baseline estimation results}

Table 2 presents the main regression results. Before turning our attention to the estimation results of Eq. 15, we first consider traditional Political Budget Cycles (PBCs) as well as countercyclical policy effects. Column (1) shows the results when estimating a standard PBC model with the inclusion of growth, but without expectations. The results clearly indicate a countercyclical response to realized growth and confirm the existence of a PBC effect. In election years the fiscal stance deteriorates (the deficit increases) by about 0.4 percentage points. Albeit mostly not significant, the control variables have the expected signs.

Column (2) tests whether governments in our sample follow countercyclical policies in the budgeting phase and allow the deficit to increase (and, therefore, the balance to deteriorate) when a downturn is forecast. Although the coefficient is sizable, implying that an expected downturn on average leads to an 0.5 percentage points reduction in the fiscal balance, it is imprecisely estimated and therefore not significantly different from zero using standard criteria. ${ }^{24}$

In column (3), the PBC and the "countercyclicality" variables enter both. Taking the two strings of thought into one specification hardly changes the coefficient estimates. First, we still find a strong PBC effect. Second, any countercyclical reaction in the fiscal policy stance as measured by the fiscal balance appears to be driven by realized growth; no significant effect appears to stem from forward-looking politicians that foresee a downturn.

Our theory does, however, suggest that these two channels are not independent, i.e. the policy response to a forecasted downturn may be modified when there is an election expected at the same time. To test our theory, we include the interaction of the election and expected downturn dummy in column (4). This interaction effect is clearly significant and highlights that there is indeed a difference in government behaviour depending on whether a downturn is expected to occur in an election or a non-election year. ${ }^{25}$ If we look into the PBC effect, the fiscal balance is reduced by on average 0.6 percentage points of GDP in an election year for which no down-

\footnotetext{
${ }^{23}$ It shows that, in our sample, the primary budget is on average more or less balanced and the expected growth rate is on average about half a percentage point higher than what is realized. As shown by both the standard deviations and the minimum and maximum values, expected growth is much more stable than realized growth.

${ }^{24}$ This might potentially be caused by multicollinearity: in case of excellent forecasts, there is a high correlation between expected and realized growth. When the realized growth variable is taken out of the specification, the effect becomes marginally significant. See column (1) of Table G.3 in Appendix G.

${ }^{25}$ We do not find any evidence that the impact of realized growth depends on being in an election year or not. When we include such an interaction term, it is never significant and our estimated $\beta_{1}$ is hardly affected (see column (2) of Table G.5 in Appendix G).
} 
Table 2 Towards a baseline model

\begin{tabular}{|c|c|c|c|c|c|}
\hline Primary fiscal balance & $\begin{array}{c}\text { (1) } \\
\text { Only PBC }\end{array}$ & $\begin{array}{c}\text { (2) } \\
\text { Downtum exp. } \\
\text { Countercyclical }\end{array}$ & $\begin{array}{c}\text { (3) } \\
\text { Downturn exp. } \\
\text { No interaction }\end{array}$ & $\begin{array}{c}\text { (4) } \\
\text { Downturn exp. } \\
\text { Baseline }\end{array}$ & $\begin{array}{c}(5) \\
\text { Growth exp. } \\
\text { Baseline }\end{array}$ \\
\hline Realized growth & $\begin{array}{l}0.237 * * * \\
(5.170)\end{array}$ & $\begin{array}{l}0.225^{* * * *} \\
(4.902)\end{array}$ & $\begin{array}{l}0.227^{* * *} * \\
(4.989)\end{array}$ & $\begin{array}{l}0.229 * * * \\
(5.026)\end{array}$ & $\begin{array}{l}0.220 * * * \\
(4.832)\end{array}$ \\
\hline Election dummy & $\begin{array}{c}-0.388 * * * \\
(-2.805)\end{array}$ & & $\begin{array}{l}-0.371 * * \\
(-2.618)\end{array}$ & $\begin{array}{l}-0.597 * * * \\
(-3.716)\end{array}$ & $\begin{array}{l}-0.384^{* * * *} \\
(-2.753)\end{array}$ \\
\hline Expected Economy & & $\begin{array}{l}-0.507 \\
(-1.361)\end{array}$ & $\begin{array}{l}-0.481 \\
(-1.284)\end{array}$ & $\begin{array}{l}-0.625 \\
(-1.601)\end{array}$ & $\begin{array}{c}0.174 \\
(0.894)\end{array}$ \\
\hline Election $\mathrm{x}$ Expected Economy & & & & $\begin{array}{l}0.591 * * \\
(2.096)\end{array}$ & $\begin{array}{l}-0.315^{*} \\
(-1.911)\end{array}$ \\
\hline Lagged inflation rate & $\begin{array}{l}0.0556 \\
(1.033)\end{array}$ & $\begin{array}{l}0.0520 \\
(1.000)\end{array}$ & $\begin{array}{l}0.0516 \\
(0.993)\end{array}$ & $\begin{array}{l}0.0512 \\
(0.985)\end{array}$ & $\begin{array}{l}0.0529 \\
(1.012)\end{array}$ \\
\hline $\begin{array}{l}\text { Total natual resources rents } \\
\text { (\% of lagged GDP) }\end{array}$ & $\begin{array}{c}0.156 \\
(1.454)\end{array}$ & $\begin{array}{c}0.159 \\
(1.511)\end{array}$ & $\begin{array}{c}0.159 \\
(1.510)\end{array}$ & $\begin{array}{c}0.159 \\
(1.538)\end{array}$ & $\begin{array}{c}0.147 \\
(1.398)\end{array}$ \\
\hline Under IMF program & $\begin{array}{l}-0.368 \\
(-0.632)\end{array}$ & $\begin{array}{l}-0.258 \\
(-0.458)\end{array}$ & $\begin{array}{l}-0.281 \\
(-0.503)\end{array}$ & $\begin{array}{l}-0.269 \\
(-0.480)\end{array}$ & $\begin{array}{l}-0.350 \\
(-0.640)\end{array}$ \\
\hline Lagged age dependency ratio & $\begin{array}{l}-0.0196 \\
(-0.444)\end{array}$ & $\begin{array}{l}-0.00928 \\
(-0.215)\end{array}$ & $\begin{array}{l}-0.0121 \\
(-0.280)\end{array}$ & $\begin{array}{l}-0.0110 \\
(-0.254)\end{array}$ & $\begin{array}{l}-0.0150 \\
(-0.343)\end{array}$ \\
\hline Lagged public debt (\% of GDP) & $\begin{array}{c}0.0411^{* * * *} \\
(4.125)\end{array}$ & $\begin{array}{l}0.0420^{* * * *} \\
(4.337)\end{array}$ & $\begin{array}{l}0.0419 * * * \\
(4.310)\end{array}$ & $\begin{array}{l}0.0418 * * * \\
(4.321)\end{array}$ & $\begin{array}{l}0.0432 * * * \\
(4.426)\end{array}$ \\
\hline Lagged population growth & $\begin{array}{l}-0.0797 \\
(-0.288)\end{array}$ & $\begin{array}{l}-0.102 \\
(-0.374)\end{array}$ & $\begin{array}{l}-0.0912 \\
(-0.332)\end{array}$ & $\begin{array}{l}-0.0912 \\
(-0.329)\end{array}$ & $\begin{array}{l}-0.0843 \\
(-0.301)\end{array}$ \\
\hline Lagged KOF globalisation index & $\begin{array}{c}0.125 \\
(1.491)\end{array}$ & $\begin{array}{c}0.117 \\
(1.416)\end{array}$ & $\begin{array}{c}0.116 \\
(1.394)\end{array}$ & $\begin{array}{c}0.115 \\
(1.394)\end{array}$ & $\begin{array}{c}0.127 \\
(1.508)\end{array}$ \\
\hline Adjusted R-squared & 0.317 & 0.316 & 0.318 & 0.319 & 0.320 \\
\hline Number of observations & 1064 & 1064 & 1064 & 1064 & 1064 \\
\hline Number of countries & 74 & 74 & 74 & 74 & 74 \\
\hline Number of years & 17 & 17 & 17 & 17 & 17 \\
\hline Hausman test & 0.000 & 0.000 & 0.000 & 0.000 & 0.000 \\
\hline Breusch-Pagan LM test & 0.000 & 0.000 & 0.000 & 0.000 & 0.000 \\
\hline F-test time fixed effects & 0.000 & 0.000 & 0.000 & 0.000 & 0.000 \\
\hline F-test Election & & & & 0.002 & 0.009 \\
\hline F-test Expected economy & & & & 0.074 & 0.168 \\
\hline
\end{tabular}

Notes: Standard errors are clustered at the country level. $* * * p<0.01, * * p<0.05, * p<0.1$. t-statistics are shown inside brackets. p-values are shown for test statistics. Country- and year-fixed effects are not shown.

turn is expected. However, this effect is nullified in case a downturn is expected: the interaction term is close to +0.6 percentage points. Note that the expected downturn effect in an election year is opposite to what some might have expected: the government stimulates less, not more, when voters face a more dire situation. Note also that the reduction in the PBC effect is actually stronger than suggested by Fig. 1 in the Introduction.

When replacing our expected downturn dummy by the forecasted growth rate, the interpretation of the individual coefficients turns slightly more complicated. Not only do the signs of the ExpectedEconomy coefficient and the interaction term switch, also the Election coefficient presented in column (5) can only be easily interpreted when the ExpectedEconomy is held constant at a value of 0. To allow comparison with the other columns, we, therefore, normalize this variable around zero at 


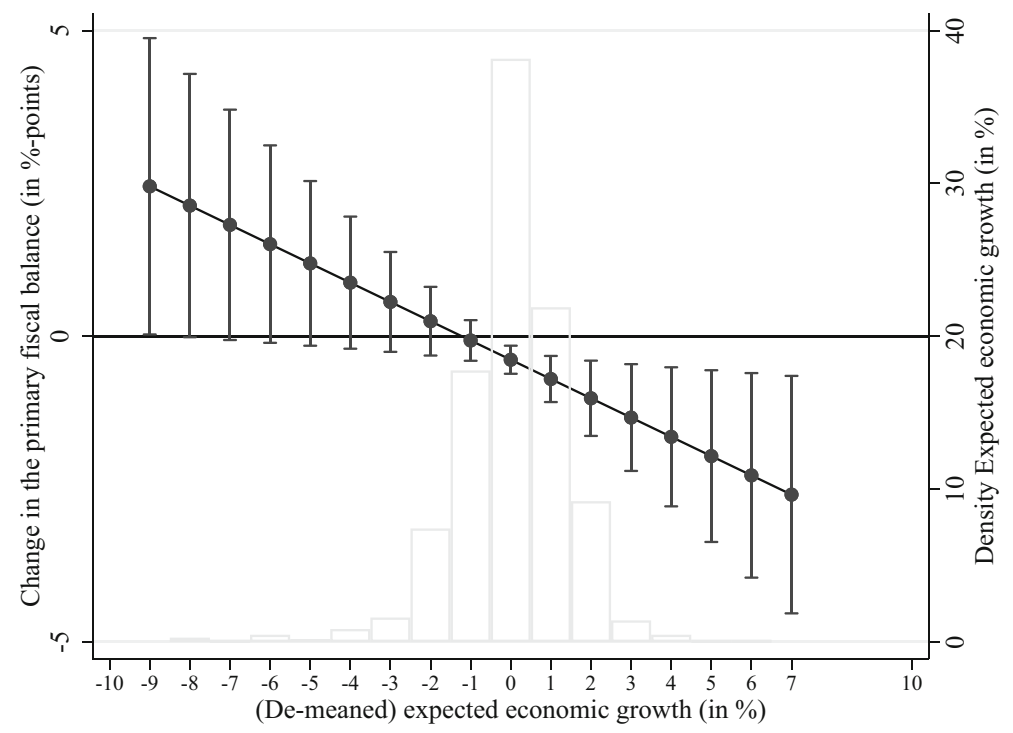

Fig. 2 Marginal effects of elections on the primary fiscal balance depending on expected growth. Notes: Whiskers show $90 \%$ confidence bands. This plot is based on column (5) of Table 2

the country level. In case of average growth expectations (ExpectedEconomy = Election $*$ Expected Economy $=0$ ), there appears to be a significant PBC effect: the deficit is increased by almost 0.4 percentage points in election years. If, however, the expected growth rate is one percentage point below average, this effect basically nullifies $(-0.384+(-1 *-0.315)=-0.069)$.

In columns (4) and (5), the F-test on the joint significance of the two coefficients involving the election variable reflects, with p-values of $0.2 \%$ and $0.9 \%$, respectively, that the context-conditional PBC we postulate is statistically significant. ${ }^{26}$

To analyse the effect of growth expectations on the PBC effect more systematically, we follow the suggestions of Brambor et al. (2006) and Hainmueller et al. (2019) and present a marginal effects plot in Fig. 2 together with a histogram of at the country level de-meaned expected growth rates. It does, therefore, show the size of the PBC effect at different expected (de-meaned) growth levels. The traditional $\mathrm{PBC}$ effect disappears as soon as growth forecasts fall below the average. Average or above-average growth expectations are associated with a significant PBC effect.

\footnotetext{
${ }^{26}$ To double-check this, we carry out a Monte-Carlo simulation. Based upon the observed country-specific occurance of elections, we randomly assign elections to years, re-run the regression shown in Column (5) of Table 2 and repeat this F-test on the joint significance of the election coefficients. This is repeated 10,000 times. In only $0.01 \%$ of these cases, we find an F-statistic that is larger than the one reported in Table 2. Figure G.1 in Appendix G shows the distribution of the estimated F-statistics based upon these Monte-Carlo simulations.
} 


\section{Robustness checks}

For the robustness checks in this and the following section, we use the expected growth specification in column (5) of table 2 as our baseline specification. It has a slightly better fit than the expected downturn specification of column (4) as measured by the adjusted R-squared in Table $2 .{ }^{27}$ For ease of comparison, Table 3 first reproduces our expected growth baseline specification. Next, we show that the selection of our control variables is inconsequential. In column (2), we follow a general-tospecific approach and stepwise remove those control variables that are insignificant. Besides slightly reducing the adjusted R-squared (despite fewer variables being used), this hardly influences the estimated results. ${ }^{28}$

The robustness checks presented in columns (3) to (5) of Table 3 relate to the definition of our election variable. First, we distinguish between presidential and parliamentary elections in column (3). As described in the previous section, our election variable does not distinguish between presidential and parliamentary systems. In Column (3) of Table 3, we test to what extent results differ between these systems. Whereas the traditional PBC effect is larger (in absolute terms) for presidential systems versus parliamentary systems (-0.6 vs. -0.3$)$, the opposite holds for the interaction factors $(-0.1$ vs. -0.4$)$. The estimated interaction coefficient is only significant for parliamentary systems. As the F-test reported in the last row of this table shows, these differences are by no means statistically significant.

Second, it is important for our theoretical argument that, when a downturn is expected to occur, the incumbent is able to affect the fiscal balance before the actual election takes place. This is more difficult in case elections are scheduled to take place early in the year. In Column (4) of Table 3, we, therefore, remove elections scheduled for the first two months of a year from our election variable. As shown, the results are hardly affected by this. ${ }^{29}$ Third, the Database of Political Institutions (DPI) allows us to construct an alternative election dummy variable. In line with the literature, we have, so far, used the information on legislative and executive elections in all of our specifications to construct an overall election dummy. Instead we can also use the variable YRCURNT that measures the years left in the current term. Following e.g. Brender and Drazen (2005) and Katsimi and Sarantides (2012), this allows us to distinguish between regular and irregular elections. Even though the traditional PBC argument continues to hold, if irregular elections are set by the incumbent, we would like to rule out that these irregular elections are, perhaps for very different reasons driving our results. ${ }^{30}$ In column (5) of Table 3 we remove those

\footnotetext{
${ }^{27}$ The robustness checks when using the expected downturn dummy are reported in Table G.4 of Appendix G. The qualitative conclusions are, in general, not affected by this.

${ }^{28}$ Also removing all controls, or moving to a country-random effects model, hardly affects coefficients (or the significance) of our variables of interest (see column (5) of Table G.3 in Appendix G).

${ }^{29}$ Whether, in case of these early elections, we remove the observations altogether or set the election variable equal to zero does not matter for the results in any meaningful way.

${ }^{30}$ More generally, one might worry about the orthogonality of elections and expected growth. However, neither our expected downturn dummy, nor expected growth is significantly correlated with our election variable. See also Footnote 21.
} 
Table 3 Some robustness check

\begin{tabular}{|c|c|c|c|c|c|c|c|}
\hline Primary fiscal balance & $\begin{array}{l}\text { (1) } \\
\text { Growth exp. } \\
\text { Baseline }\end{array}$ & $\begin{array}{l}\text { (2) } \\
\text { Growth exp. } \\
\text { Gen-to-spec. }\end{array}$ & $\begin{array}{l}\text { (3) } \\
\text { Growth exp. } \\
\text { Pres.-parl. }\end{array}$ & $\begin{array}{c}\text { (4) } \\
\text { Growth exp. } \\
\text { No early elections }\end{array}$ & $\begin{array}{c}\text { (5) } \\
\text { Growth exp. } \\
\text { Regular elections }\end{array}$ & $\begin{array}{l}\text { (6) } \\
\text { Growth exp. } \\
\text { No extremes }\end{array}$ & $\begin{array}{c}\text { (7) } \\
\text { Growth exp. } \\
\text { More democracies }\end{array}$ \\
\hline Realized growth & $\begin{array}{l}0.220 * * * \\
(4.832)\end{array}$ & $\begin{array}{l}0.226^{* * * *} \\
(5.018)\end{array}$ & $\begin{array}{l}0.219 * * * \\
(4.785)\end{array}$ & $\begin{array}{l}0.217 * * * \\
(4.672)\end{array}$ & $\begin{array}{c}0.213 * * * \\
(4.526)\end{array}$ & $\begin{array}{l}0.245^{* * * *} \\
(4.814)\end{array}$ & $\begin{array}{l}0.171 * * * \\
(4.174)\end{array}$ \\
\hline Election dummy & $\begin{array}{l}-0.384^{* * * *} \\
(-2.753)\end{array}$ & $\begin{array}{l}-0.383^{*} * * \\
(-2.748)\end{array}$ & & $\begin{array}{l}-0.352^{* * *} \\
(-2.193)\end{array}$ & $\begin{array}{l}-0.390 * * \\
(-2.479)\end{array}$ & $\begin{array}{l}-0.323^{* * *} \\
(-2.260)\end{array}$ & $\begin{array}{l}-0.419 * * \\
(-2.496)\end{array}$ \\
\hline Election in presidential system & & & $\begin{array}{l}-0.581^{*} * \\
(-2.321)\end{array}$ & & & & \\
\hline Election in parliamentary system & & & $\begin{array}{l}-0.321^{*} \\
(-1.759)\end{array}$ & & & & \\
\hline Expected Economy & $\begin{array}{c}0.174 \\
(0.894)\end{array}$ & $\begin{array}{c}0.217 \\
(1.060)\end{array}$ & $\begin{array}{c}0.172 \\
(0.882)\end{array}$ & $\begin{array}{c}0.189 \\
(0.965)\end{array}$ & $\begin{array}{c}0.193 \\
(0.970)\end{array}$ & $\begin{array}{c}0.284 \\
(1.211)\end{array}$ & $\begin{array}{c}0.0982 \\
(0.750)\end{array}$ \\
\hline Election $\mathrm{x}$ Expected Economy & $\begin{array}{l}-0.315^{*} \\
(-1.911)\end{array}$ & $\begin{array}{l}-0.333^{*} \\
(-1.942)\end{array}$ & & $\begin{array}{l}-0.314^{*} \\
(-1.768)\end{array}$ & $\begin{array}{l}-0.398^{*} \\
(-1.922)\end{array}$ & $\begin{array}{l}-0.509 * * \\
(-2.485)\end{array}$ & $\begin{array}{l}-0.285^{* *} \\
(-2.152)\end{array}$ \\
\hline Presidential Election x Exp.Ec. & & & $\begin{array}{c}-0.122 \\
(-0.500)\end{array}$ & & & & \\
\hline Parliamentary Election $x$ Exp.Ec. & & & $\begin{array}{l}-0.374^{*} \\
(-1.959)\end{array}$ & & & & \\
\hline Lagged inflation rate & $\begin{array}{l}0.0529 \\
(1.012)\end{array}$ & & $\begin{array}{l}0.0563 \\
(1.064)\end{array}$ & $\begin{array}{l}0.0524 \\
(1.028)\end{array}$ & $\begin{array}{l}0.0640 \\
(1.279)\end{array}$ & $\begin{array}{l}0.0397 \\
(0.766)\end{array}$ & $\begin{array}{l}0.0582^{*} \\
(1.904)\end{array}$ \\
\hline $\begin{array}{l}\text { Total natural resources rents } \\
\text { (\% of lagged GDP) }\end{array}$ & $\begin{array}{c}0.147 \\
(1.398)\end{array}$ & & $\begin{array}{c}0.148 \\
(1.398)\end{array}$ & $\begin{array}{c}0.136 \\
(1.297)\end{array}$ & $\begin{array}{c}0.136 \\
(1.312)\end{array}$ & $\begin{array}{c}0.163 \\
(1.458)\end{array}$ & $\begin{array}{c}0.144^{* * * *} \\
(2.623)\end{array}$ \\
\hline Under IMF program & $\begin{array}{c}-0.350 \\
(-0.640)\end{array}$ & & $\begin{array}{c}-0.347 \\
(-0.622)\end{array}$ & $\begin{array}{c}-0.298 \\
(-0.574)\end{array}$ & $\begin{array}{c}-0.335 \\
(-0.646)\end{array}$ & $\begin{array}{c}-0.487 \\
(-0.853)\end{array}$ & $\begin{array}{c}0.129 \\
(0.330)\end{array}$ \\
\hline Lagged age dependency ratio & $\begin{array}{l}-0.0150 \\
(-0.343)\end{array}$ & & $\begin{array}{l}-0.0177 \\
(-0.402)\end{array}$ & $\begin{array}{l}-0.0213 \\
(-0.462)\end{array}$ & $\begin{array}{l}-0.0222 \\
(-0.491)\end{array}$ & $\begin{array}{l}-0.0112 \\
(-0.258)\end{array}$ & $\begin{array}{l}-0.0214 \\
(-0.441)\end{array}$ \\
\hline Lagged public debt ( $\%$ of GDP) & $\begin{array}{c}0.0432 * * * \\
(4.426)\end{array}$ & $\begin{array}{c}0.0398 * * * \\
(3.934)\end{array}$ & $\begin{array}{c}0.0429 \text { *** } \\
(4.453)\end{array}$ & $\begin{array}{c}0.0438 * * * \\
(4.521)\end{array}$ & 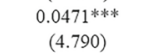 & $\begin{array}{c}0.0434^{* * * *} \\
(4.340)\end{array}$ & $\begin{array}{c}0.0270^{*} \text { *** } \\
(2.928)\end{array}$ \\
\hline Lagged population growth & $\begin{array}{l}-0.0843 \\
(-0.301)\end{array}$ & & $\begin{array}{l}-0.0837 \\
(-0.298)\end{array}$ & $\begin{array}{l}-0.120 \\
(-0.425)\end{array}$ & $\begin{array}{l}-0.0615 \\
(-0.237)\end{array}$ & $\begin{array}{l}-0.0120 \\
(-0.0430)\end{array}$ & $\begin{array}{c}0.142 \\
(0.432)\end{array}$ \\
\hline Lagged KOF globalisation index & $\begin{array}{c}0.127 \\
(1.508)\end{array}$ & & $\begin{array}{c}0.127 \\
(1.510)\end{array}$ & $\begin{array}{c}0.124 \\
(1.452)\end{array}$ & $\begin{array}{l}0.150 * \\
(1.824)\end{array}$ & $\begin{array}{c}0.126 \\
(1.569)\end{array}$ & $\begin{array}{c}0.110 \\
(1.406)\end{array}$ \\
\hline Adjusted R-squared & 0.320 & 0.308 & 0.319 & 0.319 & 0.329 & 0.311 & 0.249 \\
\hline Number of observations & 1064 & 1064 & 1064 & 1034 & 994 & 1034 & 1502 \\
\hline Number of countries & 74 & 74 & 74 & 74 & 74 & 74 & 110 \\
\hline Number of years & 17 & 17 & 17 & 17 & 17 & 17 & 17 \\
\hline Hausman test & 0.000 & 0.000 & 0.000 & 0.000 & 0.000 & 0.000 & 0.002 \\
\hline Breusch-Pagan LM test & 0.000 & 0.000 & 0.000 & 0.000 & 0.000 & 0.000 & 0.000 \\
\hline F-test time-fixed effects & 0.000 & 0.000 & 0.000 & 0.000 & 0.000 & 0.000 & 0.000 \\
\hline F-test Election & 0.009 & 0.009 & 0.029 & 0.033 & 0.002 & 0.005 & 0.000 \\
\hline F-test Expected Economy & 0.168 & 0.159 & 0.280 & 0.216 & 0.145 & 0.050 & 0.000 \\
\hline F-test pres.el=parl.el & & & 0.358 & & & & \\
\hline
\end{tabular}

election years that are not coded as regular. Once again, the qualitative results do not change. ${ }^{31}$

The previous robustness checks were motivated by the concern that some (types of) elections might drive the results. The same might hold for some (expected) economic developments. To check how robust our results are along that dimension, we remove realized or expected growth observations that are potential outliers, i.e. are relatively extreme. Following Iglewicz and Hoaglin (1993), we use so-called modified Z-scores that only rely on outlier-robust metrics to identify relatively extreme

\footnotetext{
${ }^{31}$ Replacing the election dummy by a variable that actually measures the years left in the current term (YRCURNT) does also not have a noteworthy effect on the results (not shown). Also replacing the election variable of the baseline model with an election dummy that includes only those elections that are coded as regular, turning irregular election years into non-election years, does not change any of the conclusions either.
} 


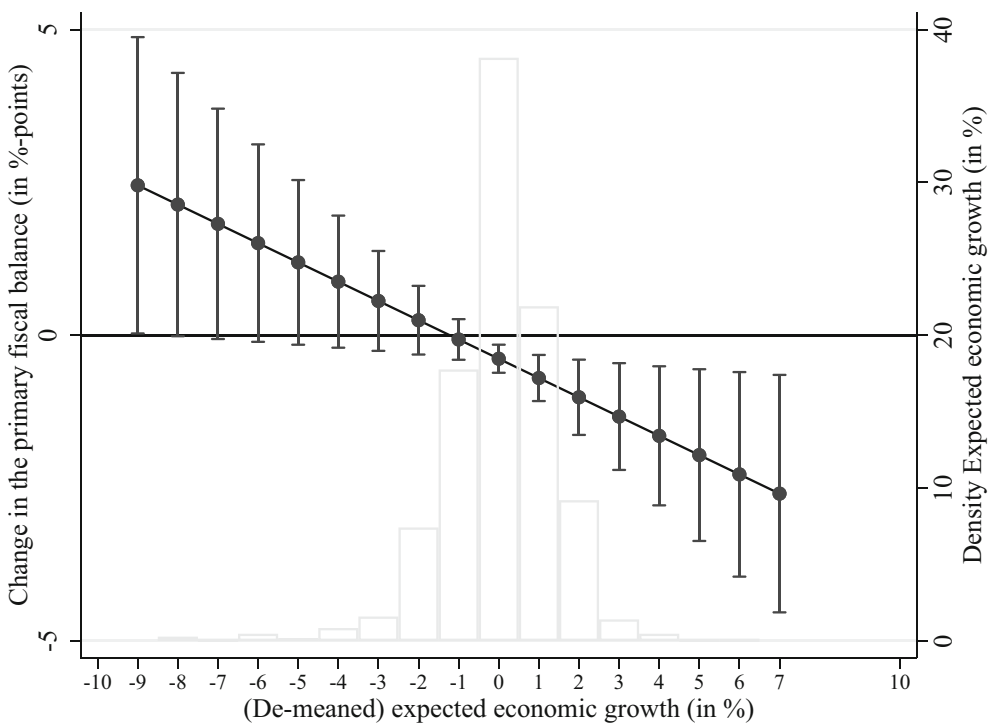

Fig. 3 Marginal effects of elections on the primary fiscal balance depending on expected growth using a broader definition of democracies. Note: Whiskers show $90 \%$ confidence bands. This plot is based on column (7) of Table 3 and includes democracies as defined by Cheibub et al. (2010) and Bjørnskov and Rode (2020)

(expected) growth observations. ${ }^{32}$ This takes 30 observations out of our sample. Column (6) in Table 3 shows that these relatively extreme growth observations do not have a large impact on most of the coefficient estimates and are therefore not socalled bad leverage points. If anything, our estimate for $\beta_{4}$ becomes somewhat larger and statistically significant at a lower level.

Instead of reducing the sample, by removing potential outliers, we can increase it by using a loser definition of when a country is labeled a democracy. When we move to the definition of Cheibub et al. (2010) as updated by Bjørnskov and Rode (2020), the number of countries classified as a democracy increases to 110 . As the last column of Table 3 and Fig. 3 shows, this does not affect our conclusions. On the contrary, our results become slightly stronger when using this larger sample of democracies.

\section{Robustness checks on context-conditionality}

In a final set of robustness checks, we discuss the claim of e.g. Franzese (2002) and Alt and Rose (2007) and Dubois (2016) that PBCs are context-conditional along other dimensions than expected growth, i.e. do not occur in all countries or situations at all

\footnotetext{
${ }^{32}$ To be precise, the modified Z-score is defined as $0.6745\left(x_{i t}-y\right) / M A D$ with $M A D$ denoting the median absolute deviation, and $y$ denoting the median of variable $x$. Observations with a modified Z-score larger than 3.5 (in absolute value) are removed from our sample.
} 
times, for different reasons than introduced here. For this, we first check whether the interaction of other control variables taken up in our model with our election dummy affect the channel we discuss. Subsequently, we include proxies for alternative theories that have so far been used in the literature to explain in what kind of countries or situations a PBC effect is to be expected.

For three out of the eight controls that are included in our baseline equation, we find a significant effect when interacted with our election dummy. Columns (2) to (4) in Table 4 refer to inflation, age dependency and globalization. Higher inflation or an increased age dependency ratio are associated with a worsening of the primary fiscal balance in election years. In contrast, a higher degree of globalization goes hand in hand with an improved primary fiscal balance during election years. Globalization thereby reduces the PBC effect considerably. ${ }^{33}$ Although interesting in itself, what is relevant for this paper is the finding that this does not alter the impact growth expectations have on the fiscal balance when elections are coming up. Our main variable of interest is neither affected qualitative, nor is the change quantitatively noticeable. $^{34}$

According to the work of Alt and Lassen (2006a b), Akhmedov and Zhuravskaya (2004) and Klomp and De Haan (2016) and Veiga et al. (2017) PBCs occur, in particular, in countries with a high degree of intransparency in fiscal or government policies or a lack of media freedom, respectively. To account for this, we use the measures of Bureaucratic Quality published by the International Country and Risk Guide (ICRG) and the Freedom of the Press Scores published by Freedom House. Often it is also argued that PBCs mainly occur in developing countries (Schuknecht 1996, 2000; Block, 2002; Shi and Svensson, 2006; and Vergne, 2009), or in new democracies (Brender and Drazen 2005). For this, we interact our election variable with dummies for core OECD countries (defined as those OECD countries that have been long-standing members) ${ }^{35}$ and new democracies (in particular those that turned democratic after the fall of the iron curtain). ${ }^{36}$ Finally, the political system

\footnotetext{
${ }^{33}$ In a different robustness check, we reduced the sample by removing less-globalized countries. Countries that are highly globalized are more affected and driven by international business cycles, which implies that short-term growth dynamics are more likely to be exogenous. Even when concentrating on only that half of the sample representing high globalization levels, the qualitative results do not change. The interaction term remains significantly negative and the estimated marginal effects (not shown) still indicate that the $\mathrm{PBC}$ effect is only statistically significant in case we observe sufficiently high growth expectations (i.e. the de-meaned growth expectations are at or above zero). For low growth expectations, there is never a significantly negative impact of being in an election year on the fiscal balance, i.e. the PBC effect is killed in a downturn.

${ }^{34}$ This also holds for those additional interaction terms that are insignificant. See Table A.5 in Appendix G for these additional results.

${ }^{35}$ These are Australia, Austria, Belgium, Canada, Denmark, Finland, France, Germany, Greece, Iceland, Ireland, Italy, Japan, Luxembourg, the Netherlands, New Zealand, Norway, Portugal, Spain, Sweden, Switzerland, the United Kingdom, and the United States. The full set of OECD countries also includes Chile, the Czech Republic, Estonia, Hungary, Israel, South Korea, Mexico, Poland, the Slovak Republic, Slovenia, and Turkey. The results do not change in any qualitatively meaningful way when using the full set of OECD countries instead.

${ }^{36}$ These are Albania, Armenia, Azerbaijan, Belarus, Bosnia and Herzegovina, Croatia, the Czech Republic, Estonia, Georgia, Hungary, the Kyrgyz Republic, Latvia, Lithuania, Moldova, Montenegro, Poland, Romania, Russia, the Slovak Republic, Slovenia, Tajikistan, Turkmenistan, Ukraine, and Uzbekistan.
} 
Table 4 Including variables representing alternative forms of conditionality

\begin{tabular}{|c|c|c|c|c|c|c|c|}
\hline \multirow[b]{3}{*}{ Primary fiscal balance } & \multirow[b]{3}{*}{ Baseline } & (2) & (3) & (4) & $(5)$ & (6) & (7) \\
\hline & & \multicolumn{6}{|c|}{ Variable representing the alternative interaction variable } \\
\hline & & inflation & $\begin{array}{c}\text { Age } \\
\text { dependency }\end{array}$ & $\begin{array}{c}\mathrm{KOF} \\
\text { globalisation }\end{array}$ & $\begin{array}{c}\text { Bureaucratic } \\
\text { quality }\end{array}$ & $\begin{array}{l}\text { Freedom } \\
\text { of press }\end{array}$ & $\begin{array}{c}\text { core } \\
\text { OECD }\end{array}$ \\
\hline Realized growth & $\begin{array}{c}0.220 * * * \\
(4.832)\end{array}$ & $\begin{array}{c}0.221 * * * \\
(4.944)\end{array}$ & $\begin{array}{l}0.221 * * * \\
(4.842)\end{array}$ & $\begin{array}{c}0.223 * * * \\
(4.940)\end{array}$ & $\begin{array}{c}0.179 * * * \\
(3.480)\end{array}$ & $\begin{array}{l}0.223 * * * \\
(4.917)\end{array}$ & $\begin{array}{c}0.223 * * * \\
(4.928)\end{array}$ \\
\hline Election dummy & $\begin{array}{c}-(1.384 * * * \\
(-2.753)\end{array}$ & $\begin{array}{c}0.00201 \\
(0.00950)\end{array}$ & $\begin{array}{c}1.251 \\
(1.515)\end{array}$ & $\begin{array}{l}-2.120^{* * *} \\
(-2.511)\end{array}$ & $\begin{array}{c}-1.793 * * * \\
(-3.165)\end{array}$ & $\begin{array}{c}0.183 \\
(0.502)\end{array}$ & $\begin{array}{c}-0.673^{* * * *} * \\
(-3.869)\end{array}$ \\
\hline Expected Economy & $\begin{array}{c}0.174 \\
(0.894)\end{array}$ & $\begin{array}{c}0.171 \\
(0.883)\end{array}$ & $\begin{array}{c}0.170 \\
(0.872)\end{array}$ & $\begin{array}{c}0.167 \\
(0.860)\end{array}$ & $\begin{array}{c}0.243 \\
(1.124)\end{array}$ & $\begin{array}{c}0.180 \\
(0.932)\end{array}$ & $\begin{array}{c}0.171 \\
(0.882)\end{array}$ \\
\hline Election $x$ Expected Econininy & $\begin{array}{l}-0.315^{*} \\
(-1.911)\end{array}$ & $\begin{array}{l}-0.312^{\psi} \\
(-1.916)\end{array}$ & $\begin{array}{l}-0.313^{\downarrow} \\
(-1.888)\end{array}$ & $\begin{array}{l}-0.304^{\psi} \\
(-1.838)\end{array}$ & $\begin{array}{l}-0.396^{\psi \psi} \\
(-2.179)\end{array}$ & $\begin{array}{l}-0.323^{*} \\
(-1.959)\end{array}$ & $\begin{array}{l}-0.318^{\psi} \\
(-1.904)\end{array}$ \\
\hline Alternative interaction variable & & & & & $\begin{array}{l}-0.735 \\
(-0.467)\end{array}$ & $\begin{array}{l}0.0780 \\
(1.428)\end{array}$ & \\
\hline Election $x$ Alternative variable & & $\begin{array}{l}-0.107^{*} * \\
(-2.475)\end{array}$ & $\begin{array}{c}-0.0311 * * \\
(-2.022)\end{array}$ & $\begin{array}{c}0.0241 * * \\
(2.151)\end{array}$ & $\begin{array}{l}0.426^{* *} \\
(2.552)\end{array}$ & $\begin{array}{c}-0.0234^{*} \\
(-1.841)\end{array}$ & $\begin{array}{l}0.727 * * \\
(2.504)\end{array}$ \\
\hline Lagged inflation rate & $\begin{array}{l}0.0529 \\
(1.012)\end{array}$ & $\begin{array}{l}0.0751 \\
(1.477)\end{array}$ & $\begin{array}{l}0.0534 \\
(1.017)\end{array}$ & $\begin{array}{l}0.0521 \\
(0.996)\end{array}$ & $\begin{array}{l}0.107^{* *} * \\
(2.272)\end{array}$ & $\begin{array}{l}0.0541 \\
(1.042)\end{array}$ & $\begin{array}{l}0.0526 \\
(1.004)\end{array}$ \\
\hline $\begin{array}{l}\text { Total natural resources rents } \\
\text { (\% of lagged GDP) }\end{array}$ & $\begin{array}{l}0.147 \\
(1.398)\end{array}$ & $\begin{array}{l}0.148 \\
(1.409)\end{array}$ & $\begin{array}{c}0.150 \\
(1.417)\end{array}$ & $\begin{array}{c}0.147 \\
(1.392)\end{array}$ & $\begin{array}{l}0.0726 \\
(0.803)\end{array}$ & $\begin{array}{c}0.133 \\
(1.293)\end{array}$ & $\begin{array}{c}0.146 \\
(1.393)\end{array}$ \\
\hline Under IMF program & $\begin{array}{l}-0.350 \\
(-0.640)\end{array}$ & $\begin{array}{l}-0.338 \\
(-0.616)\end{array}$ & $\begin{array}{c}-0.378 \\
(-0.688)\end{array}$ & $\begin{array}{c}-0.370 \\
(-0.673)\end{array}$ & $\begin{array}{c}-0.474 \\
(-0.799)\end{array}$ & $\begin{array}{c}-0.390 \\
(-0.714)\end{array}$ & $\begin{array}{l}-0.365 \\
(-0.662)\end{array}$ \\
\hline Lagged age dependency ratio & $\begin{array}{l}-0.0150 \\
(-0.343)\end{array}$ & $\begin{array}{l}-0.0166 \\
(-0.377)\end{array}$ & $\begin{array}{c}-0.00959 \\
(-0.223)\end{array}$ & $\begin{array}{l}-0.0174 \\
(-0.394)\end{array}$ & $\begin{array}{l}-0.0721 \\
(-0.961)\end{array}$ & $\begin{array}{l}-0.0170 \\
(-0.390)\end{array}$ & $\begin{array}{l}-0.0158 \\
(-0.362)\end{array}$ \\
\hline Lagged public debt (\% of GDP) & $\begin{array}{c}0.0432 * * * \\
(4.426)\end{array}$ & $\begin{array}{c}0.0432 * * * \\
(4.455)\end{array}$ & $\begin{array}{c}0.0431 * * * \\
(4.449)\end{array}$ & $\begin{array}{c}0.0431 * * * \\
(4.438)\end{array}$ & $\begin{array}{c}0.0428 * * * \\
(3.818)\end{array}$ & $\begin{array}{c}0.0429^{* * * *} \\
(4.581)\end{array}$ & $\begin{array}{c}0.0432 * * * \\
\quad(4.456)\end{array}$ \\
\hline Lagged population growth & $\begin{array}{l}-0.0843 \\
(-0.301)\end{array}$ & $\begin{array}{l}-0.0881 \\
(-0.309)\end{array}$ & $\begin{array}{c}-0.101 \\
(-0.358)\end{array}$ & $\begin{array}{l}-0.0876 \\
(-0.313)\end{array}$ & $\begin{array}{c}0.107 \\
(0.285)\end{array}$ & $\begin{array}{l}-0.0772 \\
(-0.271)\end{array}$ & $\begin{array}{l}-0.0837 \\
(-0.297)\end{array}$ \\
\hline Lagged $\mathrm{KOF}$ globalisation index & $\begin{array}{c}0.127 \\
(1.508)\end{array}$ & $\begin{array}{c}0.128 \\
(1.533)\end{array}$ & $\begin{array}{c}0.125 \\
(1.480)\end{array}$ & $\begin{array}{c}0.119 \\
(1.412)\end{array}$ & $\begin{array}{c}0.148 \\
(1.596)\end{array}$ & $\begin{array}{c}0.128 \\
(1.523)\end{array}$ & $\begin{array}{c}0.126 \\
(1.495)\end{array}$ \\
\hline Adjusted R-squared & 0.320 & 0.322 & 0.321 & 0.321 & 0.369 & 0.323 & 0.321 \\
\hline Number of observations & 1064 & 1064 & 1064 & 1064 & 833 & 1064 & 1064 \\
\hline Number of countries & 74 & 74 & 74 & 74 & 64 & 74 & 74 \\
\hline Number of years & 17 & 17 & 17 & 17 & 15 & 17 & 17 \\
\hline Hausman test & 0.000 & 0.000 & 0.000 & 0.000 & 0.000 & 0.000 & 0.000 \\
\hline Breusch-Pagan LM test & 0.000 & 0.000 & 0.000 & 0.000 & 0.000 & 0.000 & 0.000 \\
\hline F-test time fixed effects & 0.000 & 0.000 & 0.000 & 0.000 & 0.000 & 0.000 & 0.000 \\
\hline F-test Election & 0.009 & 0.167 & 0.045 & 0.005 & 0.004 & 0.129 & 0.001 \\
\hline F-test Expected growth & 0.168 & 0.165 & 0.174 & 0.191 & 0.090 & 0.154 & 0.170 \\
\hline F-test Altemative theory & & 0.010 & 0.135 & 0.036 & 0.042 & 0.103 & 0.015 \\
\hline
\end{tabular}

Notes: Standard errors are clustered at the country level. $* * * p<0.01, * * p<0.05, * p<0.1$ t t-statistics are shown inside brackets. p-values are shown for test statistics. Country- and year-fixed effects are not shown. In columns (2)-(4), the alternative interaction variable is part of the regular list of explanatory variables. In column (7), the altemative interaction variable does not vary over time and its non-interacted effect is captured by country-fixed effects.

(Chang, 2008 and Streb et al. 2009) and/or the electoral system (Aidt and Mooney, 2014) might affect the occurrence of a PBC effect. In the first case, we distinguish between parliamentary and presidential systems, in the latter between systems in which most seats are based on plurality vs. proportional representation. Both variables are taken from the DPI.

We include proxies of these alternative theories and interact them with our election variable to check whether our main story is affected by the inclusion of variables 
representing any of these theories. In those cases in which we find these interaction effects to be significant, we report them in Table $4 .{ }^{37}$ Even though, we do find evidence that bureaucratic quality and being part of the core OECD (and thereby having a higher level of development) are associated with a better fiscal position during election times, this does not affect the channel that is central to this paper. Contrary to expectations, press freedom is not associated with an improved fiscal situation during election years. In all cases, including those related to new democracies and the political system (parliamentary vs. presidential systems, or plurality vs. proportional representation), the coefficient for the expected growth variable interacted with elections remains significant and of a similar magnitude.

Summarizing these empirical results on the magnitude of government manipulation, we find significant differences when we combine two dimensions: (i) election versus off-election years; and (ii) the expected economic conditions (below average versus normal or above average). In election years, we find strong evidence in favor of a traditional PBC effect, if economically normal or buoyant times are expected; the incumbent reduces the fiscal balance to increase her re-election chances. However, this behavior changes, if bad times are expected. In such a situation the PBC effect is at least nullified, i.e. expected downturns kill the PBC. Our theoretical framework indicates that this is in line with a situation in which voters either underestimate the deteriorating fiscal balance (caused by automatic stabilisers) or expect precautionary government policies when economic expectations strongly deteriorate.

\section{Conclusion}

As far as we are aware, we are the first to analyse how expected downturns can theoretically and do empirically affect the traditional political budget cycle (PBC) effect, whereby opportunistic behavior of the incumbent leads to a larger deficit. Using a sample of 74 democratic countries covering the 2000-2016 period and a difference-in-differences type of estimation strategy, the empirical evidence is clearcut. In normal times and conditioning on realized growth, primary fiscal balances on average deteriorate by at least 0.6 percentage points of GDP in an election year. This clear evidence in favor of the traditional PBC effect during normal times disappears completely when focusing on those election years for which a downturn is expected. Only when normal or, in particular, high growth is expected does the government use the opportunity to influence voters through higher spending, lower taxes, or both. However, expected downturns kill this PBC effect.

How can this empirical result be theoretically explained? Within a theoretical framework that is based on Shi and Svensson (2006) and extended to allowing for expected downturns and distinguishing between planned and realized deficit, we need a situation in which voters underestimate the negative impact a downturn has on the fiscal balance. This happens when voters believe that tax revenues will not fall much, i.e. automatic stabilization is underestimated. To improve its re-election

\footnotetext{
${ }^{37}$ The other cases are shown in Table G.5 of Appendix G.
} 
chances, it suffices for the government to cut expenditures (or raise taxes), i.e. moderate automatic stabilization, as long as its overall fiscal policy stance remains more expansionary than what voters expected. If the expected downturn materializes, the overall change in fiscal policy is less countercyclical than what automatic stabilization would have produced. If the expected downturn does not materialize, fiscal policy turns procyclical.

As noted in the introduction, recent literature has stressed that PBCs are contextconditional. Both our theoretical model and the empirical results confirm this. However, whereas other papers find PBCs in countries with limited checks and balances or access to free media, in developing countries or new democracies and are affected by the political or electoral system, we find expansionary PBC effects to be relevant during expected normal or booming times, but not during expected downturns, even if these other conditionalities are taken into account.

Acknowledgments We thank four reviewers, the editor of this journal and participants of a brown bag seminar at Radboud University, research seminars at the Universities of Minho, Ariel and Calabria, the Silvaplana Workshop on Political Economy in 2017, the 11th Beyond Basic Questions Workshop in 2018, and the Annual Conferences of the European Public Choice Society (EPCS) in 2018, the International Institute of Public Finance (IIPF) in 2018, the Verein für Socialpolitik in 2018 and the European Economic Association in 2019 for helpful and constructive comments and suggestions. The usual disclaimer applies.

Open Access This article is licensed under a Creative Commons Attribution 4.0 International License, which permits use, sharing, adaptation, distribution and reproduction in any medium or format, as long as you give appropriate credit to the original author(s) and the source, provide a link to the Creative Commons licence, and indicate if changes were made. The images or other third party material in this article are included in the article's Creative Commons licence, unless indicated otherwise in a credit line to the material. If material is not included in the article's Creative Commons licence and your intended use is not permitted by statutory regulation or exceeds the permitted use, you will need to obtain permission directly from the copyright holder. To view a copy of this licence, visit http://creativecommonshorg/licenses/by/4.0/.

\section{References}

Aidt, T.S., \& Mooney, G. (2014). Voting suffrage and the political budget cycle: Evidence from the london metropolitan boroughs 1902-1937. Journal of Public Economics, 112, 53-71.

Akhmedov, A., \& Zhuravskaya, E. (2004). Opportunistic political cycles: Test in a young democracy setting. Quarterly Journal of Economics, 119(4), 1301-1338.

Aldenhoff, F.-O. (2007). Are economic forecasts of the international monetary fund politically biased? a public choice analysis. The Review of International Organizations, 2(3), 239-260.

Alesina, A., Cohen, G.D., Roubini, N. (1992). Macroeconomic policy and elections in oecd democracies. Economics and Politics, 4, 1-30.

Alesina, A., Cohen, G.D., Roubini, N. (1993). Electoral business cycles in industrial democracies. European Journal of Political Economy, 9, 1-25.

Alesina, A., Perotti, R., Tavares, J. (1998). The political economy of fiscal adjustments. Brookings Papers on Economic Activity, 29(1), 197-266.

Alesina, A., \& Roubini, N. (1990). Political cycles in OECD economies. Review of Economic Studies, 59, 663-688.

Alt, J.E., \& Lassen, D.D. (2006a). Fiscal transparency, political parties, and debt in OECD countries. European Economic Review, 50(6), 1403-1439.

Alt, J.E., \& Lassen, D.D. (2006b). Transparency, political polarization, and political budget cycles in oecd countries. American Journal of Political Science, 50(3), 530-550. 
Alt, J.E., \& Rose, S. (2007). Context-conditional political budget cycles, IN: Boix, C., StokesS, C., The Oxford Handbook of Comparative Politics, Oxford University Press, New York.

Arifin, T., \& Purnomowati, N.H. (2017). Government expenditure, political cycle \& rent-seeking. International Journal of Business and Society, 18(3), 461-468.

Atoyan, R., \& Conway, P. (2011). Projecting macroeconomic outcomes: Evidence from the IMF. The Review of International Organizations, 6(3-4), 415-441.

Auerbach, A.J., \& Gorodnichenko, Y. (2012). Measuring the output responses to fiscal policy. American Economic Journal: Economic Policy, 4(2), 1-27.

Beck, T., Clarke, G., Groff, A., Keefer, P., Walsh, P. (2001). New tools in comparative political economy: The database of political institutions. World Bank Economic Review, 15, 165-176. [Dataset downloadable at: http://go.worldbank.org/2EAGGLRZ40].

Benito, B., Bastida, F., Vicente, C. (2013). Municipal elections and cultural expenditure. Journal of Cultural Economics, 37(1), 3-32.

Bjørnskov, C., \& Rode, M. (2020). Regime types and regime change : A new dataset on democracy, coups, and political institutions. The Review of International Organizations, 15, 531-551.

Block, S.A. (2002). Political business cycles, democratization, and economic reform: The case of Africa. Journal of Development Economics, 67(1), 205-28.

Bohn, F. (2018). Political cycles: beyond rational expectations. PlosONE, 13(10), 1-23.

Bohn, F. (2019). Political budget cycles, incumbency advantage and propaganda. Economics and Politics, 31(1), 43-70.

Bohn, F., \& Veiga, F.J. (2019a). Elections, recession expectations and excessive debt: an unholy trinity. Public Choice, 31(3-4), 429-449.

Bohn, F., \& Veiga, F.J. (2019b). Political opportunism and countercyclical fiscal policy in election-year recessions. Economic Inquiry, 57(4), 2058-2081.

Bojar, A. (2017). Do political budget cycles work? a micro-level investigation of pre-electoral budgeting and its electoral consequences. Electoral Studies, 45, 29-43.

Brambor, T., Clark, W., Golder, M. (2006). Understanding interaction models: improving empirical analysis. Political Analysis, 14, 63-82.

Brender, A. (2003). The effect of fiscal performance on local government election results in israel: 19891998. Journal of Public Economics, 87(9-10), 2187-2205.

Brender, A., \& Drazen, A. (2005). Political budget cycles in new versus established democracies. Journal of Monetary Economics, 52(7), 1271-1295.

Brender, A., \& Drazen, A. (2008). How do budget deficits and economic growth affect reelection prospects? evidence from a large panel of countries. American Economic Review, 98(5), 2203-2220.

Castro, V., \& Martins, R. (2016). Are there political cycles hidden inside government expenditures?. Applied Economics Letters, 23(1), 34-37.

Chang, C.P., \& Lee, C.C. (2010). Us macroeconomic conditions and asymmetric adjustment to presidential approval. Journal of Economic Policy Reform, 13(3), 251-258.

Chang, E.C.C. (2008). Electoral incentives and budgetary spending: Rethinking the role of political institutions. The Journal of Politics, 70(4), 1086-1097.

Cheibub, J.A., Gandhi, J., Vreeland, J.R. (2010). Democracy and dictatorship revisited. Public Choice, 143(1-2), 67-101.

Cruz, C., Keefer, P., Scartascini, C. (2018). Database of political institutions 2017 (dpi2017), unpublished manuscript [Inter-American Development Bank, dataset downloadable at:. https://mydata.iadb.org/ Reform-Modernization-of-the-State/Database-of-Political-Institutions-2017/938i-s2bw].

De Haan, J., \& Klomp, J. (2013). Conditional political budget cycles:, a review of recent evidence. Public Choice, 157(3-4), 387-410.

De Haan, J., Sturm, J.E., Beekhuis, G. (1999). The weak government thesis: some new evidence. Public Choice, 101, 163-176.

Drazen, A. (2001). The political business cycle after 25 years. In Bernanke, B.S., \& Rogoff, K. (Eds.) NBER macroeconomics annual 2000, (Vol. 15 pp. 5-117). Cambridge: MIT Press.

Drazen, A., \& Eslava, M. (2010). Electoral manipulation via voter-friendly spending: Theory and evidence. Journal of Development Economics, 92(1), 39-52.

Dreher, A., Marchesi, S., Vreeland, J.R. (2008). The political economy of IMF forecasts. Public Choice, 137(1-2), 145-171.

Dreher, A. (2006). Does globalization affect growth? evidence from a new index of globalization. Applied Economics, 38(10), 1091-1110. 
Dubois, E. (2016). Political business cycles 40 years after nordhaus. Public Choice, 166, 235-259.

Franzese, R.J. Jr. (2002). Electoral and partisan cycles in economic policies and outcomes. Annual Review of Political Science, 5, 369-421.

Goulas, E., Kallandranis, C., Zervoyianni, A. (2015). Economic Outcomes and Voting Behavior: Evidence from Greece, Regent's Working Papers in Business \& Management 1506.

Gupta, S., Liu, E.X., Mulas-Granados, C. (2015). Now or later? the political economy of public investment in democracies?. European Journal of Political Economy, 101, 101-114.

Gygli, S., Haelg, F., Potrafke, N., Sturm, J.E. (2019). The KOF Globalisation Index - revisited. Review of International Organizations, 14(3), 543-574.

Hainmueller, J., Mummolo, J., Xu, Y. (2019). How much should we trust estimates from multiplicative interaction models? Simple tools to improve empirical practice. Political Analysis, 27(2), 163-192.

Hayo, B., \& Neumeier, F. (2016). Political leaders' socioeconomic background and public budget deficits: Evidence from OECD countries. Economics and Politics, 28(1), 55-78.

Iglewicz, B., \& Hoaglin, D.C. (1993). How to Detect and Handle Outliers, volume 16 of The ASQC Basic References in Quality Control: Statistical Techniques, ASQC Quality Press.

Ilzetzki, E., Mendoza, E.G., Vegh, C.A. (2013). How big (small?) are fiscal multipliers? Journal of Monetary Economics, 60, 239-254.

Katsimi, M., \& Sarantides, V. (2012). Do elections affect the composition of fiscal policy in developed, established democracies?. Public Choice, 151, 325-362.

Klomp, J., \& De Haan, J. (2016). Election cycles in natural resource rents: Empirical evidence. Journal of Development Economics, 121, 79-93.

Lewis-Beck, M.S., \& Stegmaier, M. (2000). Economic determinants of electoral outcomes. Annual Review of Political Science, 3(1), 183-219.

Peltzman, S. (1992). Voters as fiscal conservatives. The Quarterly Journal of Economics, 107(2), 327-361.

Rasmussen Reports (2010). Americans reject Keynesian economics, unpublished manuscript [Rasmussen Reports].

Rogoff, K. (1990). Equilibrium political budget cycles. American Economic Review, 80(1), 21-36.

Roubini, N., \& Sachs, J.D. (1989). Political and economic determinants of budget deficits in the industrial democracies. European Economic Review, 33(5), 903-933.

Schneider, C.J. (2010). Fighting with one hand tied behind the back: political budget cycles in the West German states. Public Choice, 142, 125-150.

Schuknecht, L. (1996). Political business cycles and fiscal policies in developing countries. Kyklos, 49(2), $155-170$.

Schuknecht, L. (2000). Fiscal policy cycles and public expenditure in developing countries. Public Choice, 102(1-2), 115-1300.

Seidman, L.S. (2015). Automatic Fiscal Policies to Combat Recessions, Abingdon. New York: Routledge.

Shi, M., \& Svensson, J. (2006). Political budget cycles: Do they differ across countries and why?. Journal of Public Economics, 90(8-9), 1367-1389.

Sims, C.A. (2003). Implications of rational inattention. Journal of Monetary Economics, 50(3), 665-690.

Streb, J.M., Lema, D., Torrens, G. (2009). Checks and balances on political budget cycles:, Cross-country evidence. Kyklos, 62(3), 426-447.

Veiga, F.J., Veiga, L.G., Morozumi, A. (2017). Political budget cycles and media freedom. Electoral Studies, 45, 88-99.

Veiga, L.G., \& Veiga, F.J. (2007). Does opportunism pay off. Economics Letters, 96, 177-182.

Vergne, C. (2009). Democracy, elections and allocation of public expenditures in developing countries. European Journal of Political Economy, 25(1), 63-77.

Publisher's note Springer Nature remains neutral with regard to jurisdictional claims in published maps and institutional affiliations. 